\title{
The Quaternary: its character and definition
}

1 Department of Earth Sciences, Brock University, 500 Glenridge Avenue, St. Catharines, Ontario L2S 3A1, Canada.Email: mjhead@brocku.ca 2 Cambridge Quaternary, Department of Geography, University of Cambridge, Downing Place, Cambridge CB2 3EN, United Kingdom.

3 Department of Geological Sciences, University of Texas at Austin, Austin, Texas 78712, U.S.A.

The Quaternary is characterised by the development of widespread glaciations in mid-northern latitudes. As a chronostratigraphic term it has attracted vigorous debate. The Quaternary, as accepted by the International Union for Quaternary Research and proposed by the International Commission on Stratigraphy, begins at 2.6 Ma within a 2.8-2.4 Ma interval of profound change in Earth's climate system. The base of the Gelasian Stage at 2.588 Ma offers an existing global stratotype section and point to define the base-Quaternary, and this will necessitate lowering the base of the Pleistocene from its current 1.8 Ma to that of the Quaternary to maintain hierarchical order. This proposal recognises the distinctive qualities of the Quaternary, complies strictly with the hierarchical requirements of the geological time scale, and respects the historical and widespread current usage of the term Quaternary.

\section{Introduction}

The Quaternary is youngest in a fourfold chronostratigraphic subdivision proposed by Arduino in 1759 (Arduino, 1760). Although Arduino never actually used the term 'quaternario', referring instead to his 'fourth order' (Vaccari, 2006), the concept has been used for nearly 250 years. The current official status for the Quaternary is that of period/system with a base at 1.8 Ma (Cowie and Bassett, 1989; Remane, 2000; see Head, Gibbard and Salvador, this issue, Figure 1). Nonetheless, the Quaternary was omitted from the influential time scale of Gradstein et al. (2004), and this action immediately sparked vigorous debate about its nature, duration, and chronostratigraphic status. Indeed, the recent time scales of Gradstein et al. (2004, 2005), while not officially sanctioned by either the International Commission on Stratigraphy (ICS) or the International Union of Geological Sciences (IUGS), have stimulated productive discussions about the status of both the Quaternary and the Tertiary.

Recent proposals concerning the status of the Quaternary have included treating it as an informal chronostratigraphic unit, and formally as a sub-period, period, or sub-era (see Pillans and Naish, 2004; Gibbard et al., 2005; Aubry et al., 2005; Walsh, 2006; Bowen and Gibbard, 2007; and Pillans, 2007 for reviews; Figure 1). Objections to its treatment as an informal term include its precise and widespread use in the literature and among technological as well as scientific communities (Salvador, 2006a, b). Claims based on historical interpretation that the Neogene Period extends to the present day, thereby rendering the term Quaternary superfluous (e.g., Berggren, 1998; Lourens et al., 2005), have been refuted (Walsh, 2006 , in press). Proposals for both sub-era and sub-period status deny the Quaternary its ubiquitous usage, and fail to respect the hierarchical nature of the stratigraphic time scale, when adopting a 2.6 Ma inception for the Quaternary.

After widely polling its constituents, the International Union for Quaternary Research (INQUA) in March 2006 notified the ICS of its requirements: the Quaternary to be of period status with its base at the GSSP of the Gelasian Stage (2.6 Ma), and that the base of the Pleistocene should also be lowered from its current 1.8 Ma to coincide with the base of the Quaternary. In May 2007, the ICS
Gradstein et al. (2004)

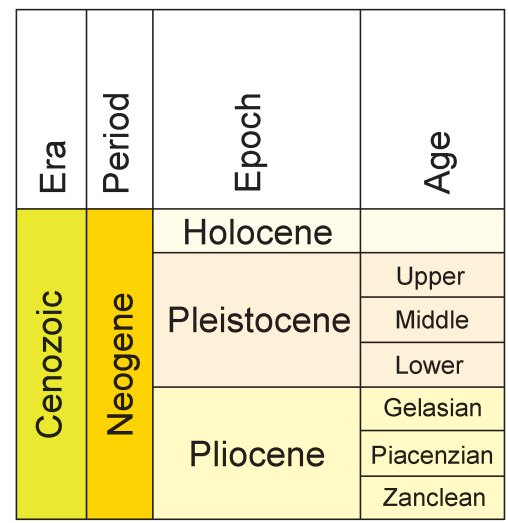

IUGS (current)

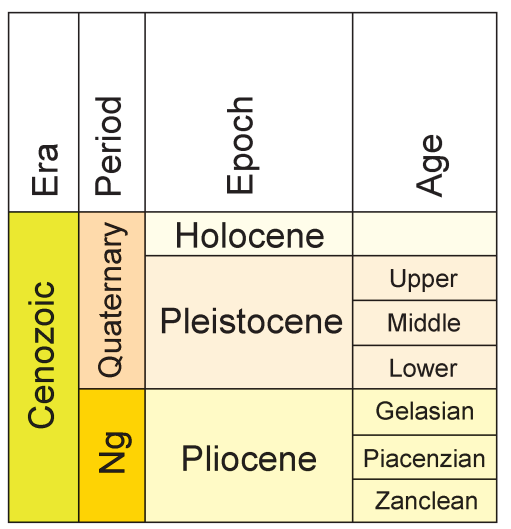

This paper

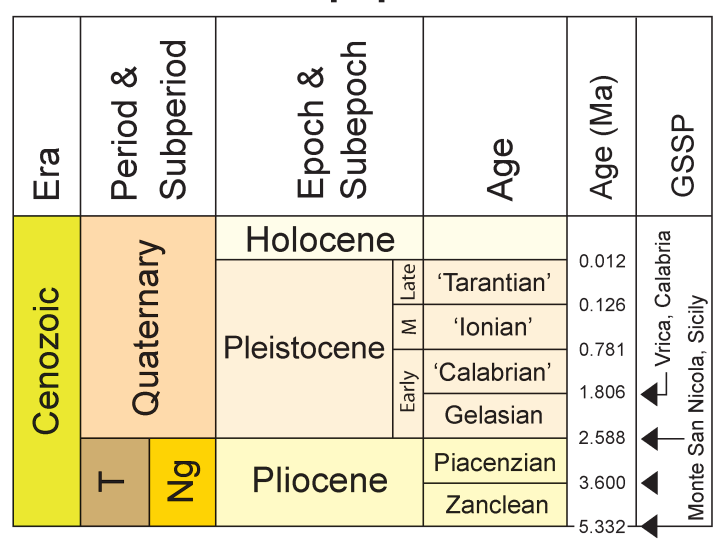

Figure 1 Comparison of late Cenozoic time scales. The Gradstein et al. (2004) time scale in which the Quaternary and Tertiary are omitted. The current IUGS-sanctioned time scale showing the Quaternary in place (Remane, 2000). In our scheme, the Quaternary and Pleistocene are co-terminous with the base-Gelasian at 2.6 Ma, in agreement with the latest INQUA and ICS proposals. The Tertiary (T) is depicted as a period/system following the proposal of Head, Gibbard and Salvador (this issue). Stage names and boundary ages are from the ICS website in January 2008, with the provisional Calabrian and Ionian stages following Cita et al. (2006) and the provisional Tarantian Stage following Cita (this issue, and references therein). Presently defined GSSPs are indicated by black triangles. Only those GSSPs mentioned in the text are labeled. $\mathrm{Ng}=$ Neogene. The illustrations are not scaled to geological time. 

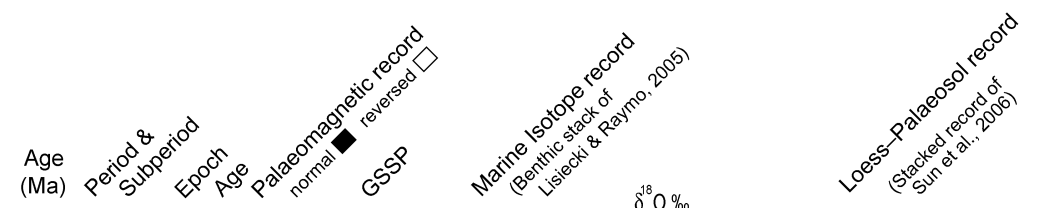

Selected events
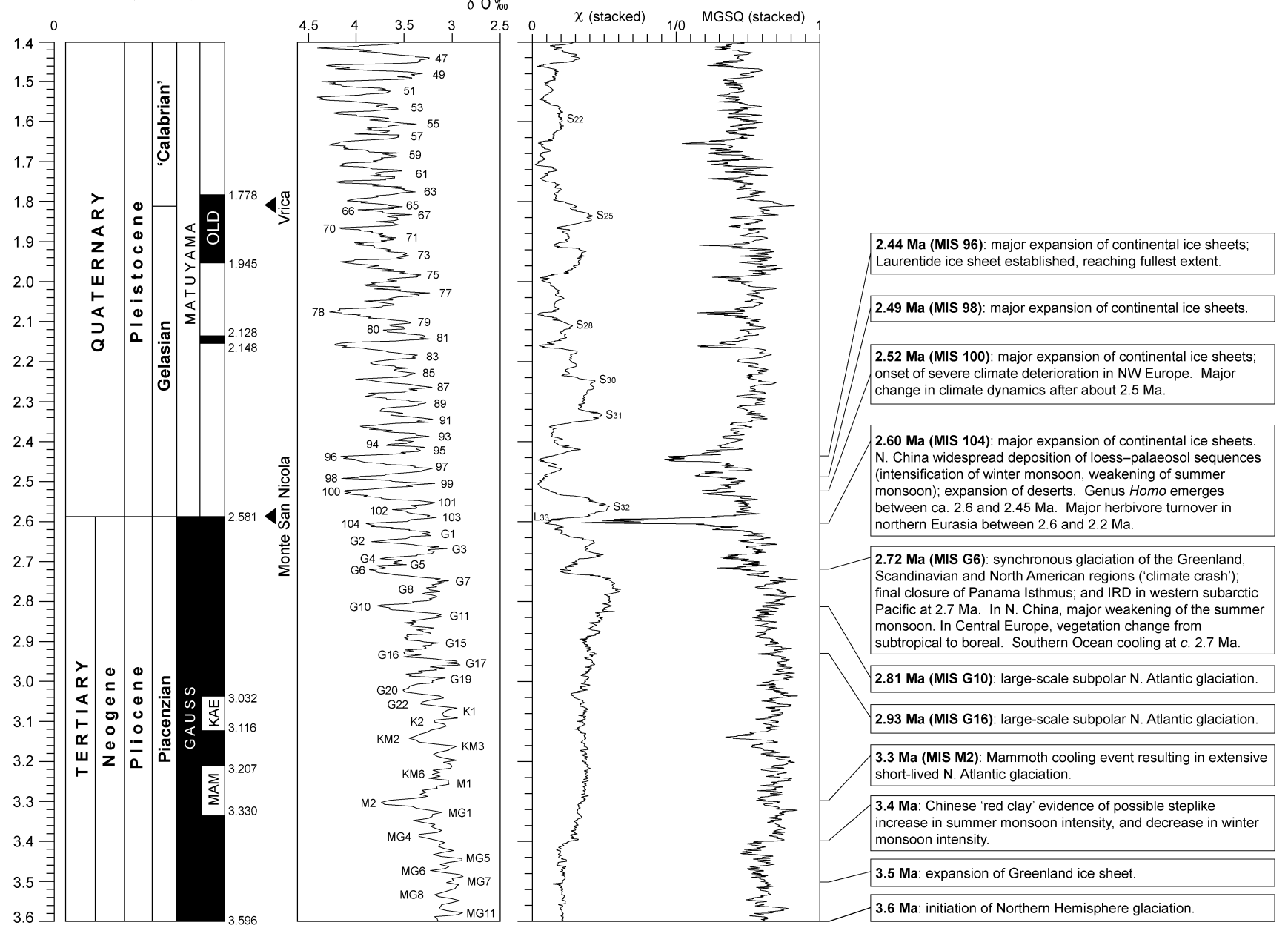

Figure 2 Selected events during the interval 1.4-3.6 Ma. Ages of magnetostratigraphic boundaries are from Lourens et al. (2005), although we note that Deino et al. (2006) gave an age of $2.610 \mathrm{Ma}$ for the Gauss-Matuyama polarity boundary. The marine benthic foraminiferal $\delta^{18} \mathrm{O}$ records and corresponding marine isotope stages are from Lisiecki and Raymo (2005), and the stacked loess-palaeosol records from the Chinese Loess Plateau ( $\chi=$ magnetic susceptibility, MGSQ = mean size of quartz grains) are from Sun et al. (2006). The Tertiary is depicted as a period/system following the proposal of Head, Gibbard and Salvador (this issue). See text for explanation of events.

voted in favour of the INQUA proposal, but the International Union of Geological Sciences (IUGS), while approving the ICS's request to accept the Quaternary as a formal period, noted in correspondence to the ICS (in May 2007) that the base of the Pleistocene could not be moved until a 10-year moratorium had expired (in January 2009). This had come about because the IUGS (but not the ICS) had voted in January 1999 to uphold the base-Pleistocene GSSP after a joint Quaternary-Neogene task group reconsidering the level of the Pliocene-Pleistocene boundary was unable to reach a supermajority recommendation (Remane and Michelsen, 1998). The current IUGS decided to impose a 10-year moratorium on that earlier base-Pleistocene decision, thereby delaying further consideration of a definition for the Quaternary and associated shifting of the Gelasian Stage to the Pleistocene until January 2009. That brings us to the present situation.

A difficulty hindering all discussions about the definition and duration of the Quaternary has been the placement in 1985 of the Pliocene-Pleistocene boundary near the top of the Olduvai Subchron (Figure 2). This boundary has since been astronomically dated at $1.806 \mathrm{Ma}$ (Lourens et al., 2005). It was defined by a Global Stratotype Section and Point (GSSP) at Vrica in Calabria, southern Italy in 1985 (Aguirre and Pasini, 1985; Cita, this issue), and reaffirmed by the IUGS in 1999 in the face of numerous objections (Gibbard et al., 2005; Bowen and Gibbard, 2007). Among these was that fundamental geological changes did not take place at or even near the chosen boundary. Indeed, some of the so-called 'northern guests', cold-tolerant migrants into the Mediterranean used as indicators of cooling at the boundary (Aguirre and Pasini, 1985), have since been found to have arrived in the Mediterranean earlier than $1.8 \mathrm{Ma}$ (e.g., Aiello et al., 1996): an age of c. 2.5-2.7 Ma is more appropriate (e.g., Suc et al., 1997). It is now well documented that major cooling events in the Mediterranean occurred between about 2.8 and 2.5 Ma (e.g., Versteegh, 1997; Monegatti and Raffi, 2001; Roveri and Taviani, 2003), which coincides with the widely agreed base of the Quaternary.

There is now overwhelming support that the Quaternary be recognised as a full period/system extending from 2.6 Ma to the present day, and that the base of the Pleistocene be lowered to that of the Quaternary in order to maintain hierarchy (Ogg and Pillans, this issue). In elucidating this position, we summarise the progressive and fundamental changes to Earth's climate system that took place between about 2.8 and $2.4 \mathrm{Ma}$, and we review the profound affects of these changes on the oceans, atmosphere, landscape and biota (Figure 2). Finally, we discuss the practicalities of defining the base of the Quaternary. 


\section{Climate evolution}

The onset of significant Northern Hemisphere glaciation at about 2.7 Ma occurs within the context of progressive Cenozoic cooling, and also a gradual increase in mean global ice volume between 3.6 and 2.4 Ma. This ice volume increase appears to be related to slow tectonic forcing, such as by mountain uplift or closure of ocean gateways (Mudelsee and Raymo, 2005). In addition, between 3.1 and 2.5 $\mathrm{Ma}$, increased amplitude in the obliquity cycle would have led to repeated cold summers in the Northern Hemisphere, thus allowing the accumulation of winter ice. A threshold appears to have been crossed at around $2.7 \mathrm{Ma}$, providing the necessary conditions for significant Northern Hemisphere glaciation to occur (Berger and Loutre, 1991; Figure 2). Late summer sea-surface temperatures in the subarctic Pacific rose in response to increased stratification (even while winter temperatures cooled), and this may have provided moisture for ice accumulation in the Arctic regions (Haug et al., 2005). Increasing warmth and intensity of North Atlantic thermohaline circulation during the warm stages from 2.95 to 2.82 Ma might also have contributed significant moisture prior to major glaciation at around 2.8 Ma, which itself may have caused eustatic closure of the Panama Isthmus thereby leading to an increase in thermohaline circulation (Bartoli et al., 2005). A freshening of the Arctic Ocean by increased fluvial runoff will have facilitated the formation of Arctic sea-ice (Driscoll and Haug, 1998). Once established, the expansion of ice sheets in the Northern Hemisphere would have amplified longterm cooling through increased albedo. Moreover, the shape of climate cycles becomes asymmetrical (saw-toothed) after about 2.5 $\mathrm{Ma}$, suggesting a major change in climate dynamics at this time (Lisiecki and Raymo, 2007).

\section{Marine records}

Ice-rafted debris (IRD) records of the Nordic Seas and North Atlantic show stepwise increase in large-scale glaciation between 3.5 and 2.4 Ma, beginning with an expansion of the Greenland ice sheet at 3.5 Ma, an extensive if short-lived glaciation at 3.3 Ma (Marine Isotope Stage [MIS] M2), and then progressive increases from 3.05 Ma (MIS G22) (Kleiven et al., 2002) including large-scale subpolar N. Atlantic glaciations at 2.93 (MIS G16) and 2.81 Ma (MIS G10) (Kleiven et al., 2002; Bartoli et al., 2005). Synchronous glaciation of the Greenland, Scandinavian and North American regions began at $2.72 \mathrm{Ma}$ (MIS G6), an event that has been called the great 'climate crash' (Bartoli et al., 2005). Indeed, a sharp increase in IRD at 2.7 Ma in the western sub-arctic Pacific indicates a synchronous circum-arctic expansion of ice sheets, benthic foraminiferal records show a rapid reorganization of the North Atlantic thermohaline circulation at 2.72 Ma (Kleiven et al., 2002; Bartoli et al., 2005; Figure 2), and calcareous nannofossil evidence documents the final (eustatic) closure of the Panama Isthmus (Kameo and Sato, 2000).

A eustatic drop of c. $45 \mathrm{~m}$ has been estimated for the period 2.93-2.82 Ma (MIS G16-G10) and a further c. $45 \mathrm{~m}$ by $2.72 \mathrm{Ma}$ (MIS G6) (Bartoli et al., 2005). Between 2.7 and 2.4 Ma, further significant ice-sheet expansions in the Nordic Seas and North Atlantic correspond to cold MIS 104, 100, 98 and 96 (Kleiven et al., 2002). This history of ice-sheet growth is mirrored in a major reorganization of the northern high-latitude marine faunal provinces (Bartoli et al., 2005).

Changes were not restricted to the Northern Hemisphere. In the Southern Ocean, the onset of water column stratification at $2.7 \mathrm{Ma}$ mirrors that of the subarctic Pacific and was caused by global cooling, and such stratification might have trapped $\mathrm{CO}_{2}$ in the abyssal depths of the world's ocean, providing a positive feedback for further cooling (Sigman et al., 2004). Synchronous peaks in ice-rafted debris (IRD) at 2.9-2.7 Ma off the Antarctic Peninsula and SE Greenland attest to this being a bipolar event (St. John, 2004).

\section{Continental records}

Ice sheet expansion occurred in Iceland during MIS G6 and especially G4 and onwards (Geirsdottir and Eiriksson, 1994; Kleiven et al., 2002), and the North American Laurentide ice sheet reached its fullest extent during its initial expansion at c. $2.4 \mathrm{Ma}$ (the Atlanta till; Balco et al., 2005; Ehlers and Gibbard, this issue).

In northern China, the widespread deposition of loess-palaeosol sequences, accompanied by significant expansion of deserts, began abruptly at $2.6 \mathrm{Ma}$ as a result of the intensification of the East-Asian winter monsoon and weakening of the summer monsoon (Ding et al., 2005). Since the altitude of the southern plateau of Tibet had not changed substantially since the mid-Pliocene, strong aridification associated with the onset of major loess-paleosol deposition at c. 2.6 Ma was largely brought about by Northern Hemisphere glaciation and the concomitant strengthening of the Siberian high-pressure cell (Ruddiman and Kutzbach, 1989), with other factors also playing a role (Ding et al., 2005). Orbitally-tuned records of the underlying red-clay sequence show a major weakening of the summer monsoon at 2.72 Ma (Sun et al., 2006; Figure 2) which coincides with the cold MIS G6. Between about 2.8 and $2.4 \mathrm{Ma}$, there also occurred the progressive aridification of Northwest Africa (Leroy and Dupont, 1994).

In central Europe, vegetation was changing from subtropical to boreal at around the same time (MIS G6-G4) (Willis et al., 1999). In Northwest Europe, an initial cooling likely representing MIS G6-G4 is reflected by the Reuverian B2 pollen substage, and this was followed by a severely cold climatic phase (Praetiglian pollen stage) directly correlated to MIS 100, 98 and 96 (2.54-2.43 Ma; Kuhlmann et al., 2006).

In Northern Eurasia, a major herbivore turnover between 2.6 and 2.2 Ma represents the emergence of the Palearctic zoogeographical province. It is characterized by the appearance of large modern ruminants and was driven by aridity as well as overall cooling and seasonal contrasts in temperature (Brugal and Croitor, 2007) that led to an opening of the landscape. The evolution of hominins and notably the emergence of the genus Homo between c. 2.6 and 2.45 Ma (Deino et al., 2006; Prat, 2007) were probably driven by the extreme climatic fluctuations at this time (Deino et al., 2006).

\section{Base of the Quaternary}

While the Quaternary is generally characterised by widespread Northern Hemisphere mid-latitude glaciation, cooling was both global and episodic. Multiple major cooling phases occurred between 2.8 and $2.4 \mathrm{Ma}$ (MIS G10 to MIS 96), and their expression varied according to region (North Atlantic IRD at $2.74 \mathrm{Ma}$, loess-palaeosol accumulation in China at $2.6 \mathrm{Ma}$, severe cooling in NW Europe at $2.54 \mathrm{Ma}$, incoming sub-Antarctic molluscs to Wanganui Basin in New Zealand at 2.4 Ma [Pillans and Naish, 2004]). No single global event emerges as a fulcrum of change. Given that boundaries must be recognized unambiguously and widely, we note that the Gauss-Matuyama polarity boundary at $2.581 \mathrm{Ma}$ (or 2.610 Ma, with a transition of $1.5 \mathrm{kyr}$, according to Deino et al., 2006), falls near the mid-point of this interval of global cooling. The base of the Gelasian Stage, defined by a GSSP at Monte San Nicola in Sicily, has an astrochronological age of $2.588 \mathrm{Ma}$. It occurs immediately above sapropel MPRS 250, corresponds to MIS 103 and is located about $1 \mathrm{~m}$ (20 kyrs) above the Gauss-Matuyama boundary (Rio et al., 1998). Given the close proximity of this existing GSSP to the Gauss-Matuyama boundary, and its calibration to the astrochronological time scale, the base-Gelasian GSSP is evidently well characterised also to define the base of the Quaternary. 


\section{Recommendation}

In our scheme, the Quaternary Period/System, Pleistocene Epoch/Series, and Gelasian Age/Stage share the same GSSP at the base-Gelasian, which is dated at $2.588 \mathrm{Ma}$. In accepting the Holocene as an epoch distinct from the Pleistocene, we recognize the fundamental impact made by modern humans on an otherwise unremarkable interglacial; and we recall the remarks of Harland et al. (1990, p. 68) that including the Holocene as a Pleistocene stage 'would run counter to history and to an immense literature and would serve no great purpose', Consequently the terms Pleistocene and Quaternary are both needed. However, on hierarchical considerations, we support ICS's and INQUA's recommendation to lower the Plio-Pleistocene boundary, but accept that the Vrica GSSP continues to define the base of the Calabrian Stage. We accept the Gelasian Stage as a useful and already familiar term, and by extension generally support use of the provisional stages Calabrian, Ionian, and Tarantian (Cita et al., 2006; Cita, this issue). Our proposed scheme (Figure 1) meets INQUA requirements, obeys the principles of a hierarchical time scale, and respects historical precedents and established usage for the term Quaternary.

\section{Acknowledgements}

This paper is based on a proposal presented at the CANQUA conference in Ottawa, June, 2007 (Head, 2007): MJH is grateful to the organisers for a stimulating meeting. We are pleased to acknowledge helpful reviews of the manuscript by Brad Pillans, Jim Ogg, and Jan Piotrowski.

\section{References}

Aguirre, E., and Pasini, G., 1985. The Pliocene-Pleistocene boundary: Episodes, 8, pp. 116-120.

Aiello, G., Barra, D., and Bonaduce, G., 1996. The genus Cytheropteron Sars, 1866 (Crustacea: Ostracoda) in the Pliocene-Early Pleistocene of the Mount San Nicola section (Gela, Sicily): Micropaleontology, 42, pp. $167-178$.

Arduino, G., 1760. Sopra varie sue Osservazioni fatte in diverse parti del Territorio di Vicenza, ed altrove, appartenenti alla Teoria Terrestre, ed alla Mineralogia. Letter to Prof. Antonio Vallisnieri, dated 30th March, 1759. Nuova Raccolta di Opuscoli Scientifici e Filologici (Venice), v. 6 (1760).

Aubry, M.-P., Berggren, W.A., Van Couvering, J., McGowran, B., Pillans, B., and Hilgen, F., 2005. Quaternary: status, rank, definition, survival: Episodes, 28, pp. 118-120.

Balco, G., Rovey II, C.W., and Stone, J.O.H., 2005. The first glacial maximum in North America: Science, 307, p. 222.

Bartoli, G., Sarnthein, M., Weinelt, M., Erlenkeuser, H., Garbe-Schönberg, D., and Lea, D.W. 2005. Final closure of Panama and the onset of northern hemisphere glaciation: Earth and Planetary Science Letters, 237, pp. 33-44.

Berggren, W.A., 1998. The Cenozoic Era: Lyellian (chrono)stratigraphy and nomenclatural reform at the millennium. In: Blundell, D.J., and Scott, A.C. (eds), Lyell: the past is the key to the present: Geological Society, London, Special Publication, 143, pp. 111-132.

Berger, A., and Loutre, M.F., 1991. Insolation values for the climate of the last 10 million years: Quaternary Science Reviews, 10, pp. 297-317.

Bowen, D.Q., and Gibbard, P.L., 2007. The Quaternary is here to stay: Journal of Quaternary Science, 22, pp. 3-8.

Brugal, J.-P., and Croitor, R., 2007. Evolution, ecology and biochronology of herbivore associations in Europe during the last 3 million years: Quaternaire, 18, pp. 129-151.

Cita, M.B., Capraro, L., Ciaranfi, N., Di Stefano, E., Marino, M., Rio, D., Sprovieri, R., and Vai, G.B., 2006. Calabrian and Ionian: A proposal for the definition of Mediterranean stages for the Lower and Middle Pleistocene: Episodes, 29, pp. 107-114.

Cowie, J.W., and Bassett, M.G. (compilers) 1989. 1989 global stratigraphic chart with geochronometric and magnetostratigraphic calibration: Episodes, 12 (2), supplement, 1 sheet.

Deino, A.L., Kingston, J.D., Glen, J.M., Edgar, R.K., and Hill, A., 2006. Precessional forcing of lacustrine sedimentation in the late Cenozoic Chemeron Basin, Central Kenya Rift, and calibration of the
Gauss/Matuyama boundary: Earth and Planetary Science Letters, 247, pp. 41-60.

Ding, Z.L., Derbyshire, E., Yang, S.L., Sun, J.M., and Liu, T.S., 2005. Stepwise expansion of desert environment across northern China in the past 3.5 Ma and implications for monsoon evolution: Earth and Planetary Science Letters, 237, pp. 45-55.

Driscoll, N.W., and Haug, G.H., 1998. A short circuit in thermohaline circulation: a cause for Northern Hemisphere Glaciation?: Science, 282, pp. $436-438$

Geirsdottir, A., and Eiriksson, J., 1994. Growth of an intermittent ice sheet in Iceland during the late Pliocene and early Pleistocene: Quaternary Research, 42, pp. 115-130.

Gradstein, F.M., Ogg, J.G., Smith, A.G., Bleeker, W., and Lourens, L.J., 2004. A new geologic time scale with special reference to the Precambrian and Neogene: Episodes, 27, pp. 83-100, with accompanying chart.

Gradstein, F.M., Ogg, J.G., and Smith, A.G. (eds.), 2005. A Geologic Time Scale 2004: Cambridge University Press, Cambridge, i-xix, pp. 1-589 [Imprinted 2004].

Gibbard, P.L. et al. (12 co-authors), 2005. What status for the Quaternary?: Boreas, 34, pp.1-6.

Harland, W.B., Armstrong, R.L., Cox, A.V., Craig, L.E., Smith, A.G., and Smith, D.G., 1990. A geologic time scale: Cambridge University Press, Cambridge, i-xvi, pp. 1-263.

Haug, G.H., Ganopolski, A., Sigman, D.M., Rosell-Mele, A., Swann, G.E.A., Tiedemann, R., Jaccard, S.L., Bollmann, J., Maslin, M.A., Leng, M.J., and Eglinton, G., 2005. North Pacific seasonality and the glaciation of North America 2.7 million years ago: Nature, 433, pp. 821-825.

Head, M.J., 2007. Tracking the status and duration of the Quaternary - a resolution in sight? CANQUA Annual Meeting: Carleton University, Ottawa, June, 2007.

Kameo, K., and Sato, T., 2000. Biogeography of Neogene calcareous nannofossils in the Caribbean and eastern equatorial Pacific - floral response to the emergence of the Isthmus of Panama: Marine Micropaleontology, 39, pp. 201-218.

Kleiven, H.F., Jansen, E., Fronval, T., and Smith, T.M., 2002. Intensification of Northern Hemisphere glaciations in the circum Atlantic region (3.5-2.4 Ma) - ice-rafted detritus evidence: Palaeogeography, Palaeoclimatology, Palaeoecology, 184, pp. 213-223.

Kuhlmann, G., Langereis, C.G., Munsterman, D., van Leeuwen, R.-J., Verreussel, R., Meulenkamp, J.E., and Wong, Th.E., 2006. Integrated chronostratigraphy of the Pliocene-Pleistocene interval and its relation to the regional stratigraphical stages in the southern North Sea region. Netherlands: Journal of Geosciences-Geologie en Mijnbouw, 85, pp. $19-35$.

Leroy, S., and Dupont, L., 1994. Development of vegetation and continental aridity in northwestern Africa during the Late Pliocene: the pollen record of ODP Site 658: Palaeogeography, Palaeoclimatology, Palaeoecology, 109 , pp. 295-316.

Lisiecki, L.E., and Raymo, M.E., 2005. A Pliocene-Pleistocene stack of 57 globally distributed benthic $\delta^{18} \mathrm{O}$ records: Paleoceanography, v. 20 PA1003, doi:10.1029/2004PA001071.

Lisiecki, L.E., and Raymo, M.E., 2007. Plio-Pleistocene climate evolution: trends and transitions in glacial cycle dynamics: Quaternary Science Reviews, 26, pp. 56-69.

Lourens, L., Hilgen, F., Shackleton, N.J., Laskar, J., and Wilson, D., 2005. The Neogene Period. In: Gradstein, F.M., Ogg, J.G., and Smith, A.G. (eds.), A Geologic Time Scale 2004: Cambridge University Press, Cambridge, pp. 409-440 [Imprinted 2004].

Monegatti, P., and Raffi, S., 2001. Taxonomic diversity and stratigraphic distribution of Mediterranean Pliocene bivalves: Palaeogeography, Palaeoclimatology, Palaeoecology, 165, pp. 171-193.

Mudelsee, M., and Raymo, M.E., 2005. Slow dynamics of the Northern Hemisphere glaciation. Paleoceanography, 20: PA4022, doi:10.1029/2005PA001153

Pillans, B., 2007. Defining the Quaternary: Where do we go from here? Stratigraphy, 4, pp. 145-149.

Pillans, B., and Naish, T., 2004. Defining the Quaternary: Quaternary Science Reviews, 23, pp. 2271-2282.

Prat, S., 2007. The Quaternary boundary: 1.8 or 2.6 millions years old? Contributions of early Homo: Quaternaire 18, pp. 99-107.

Remane, J. (compiler), 2000. International Stratigraphic Chart: International Union of Geological Sciences, and UNESCO Division of Earth Sciences, Paris.

Remane, J., and Michelsen, O., 1998. Report on the vote about the demand to lower the Plio-Pleistocene boundary (PPB). Unpublished report of the International Commission on Stratigraphy, dated 21 December 1998, 3 pp. [reproduced in Newsletter no. 6 of the International Subcommission on Stratigraphic Clasification, December 2004, pp. 5-7.]

Roveri, M., and Taviani, M., 2003. Calcarenite and sapropel deposition in the Mediterranean Pliocene: shallow- and deep-water record of astronomically driven climatic events: Terra Nova, 15, pp. 279-286.

Ruddiman, W.F., and Kutzbach, J.E., 1989. Forcing of late Cenozoic northern hemisphere climate by plateau uplift in southern Asia and the American West: Journal of Geophysical Research, 94, pp. 18409-18427. 
Rio, D., Sprovieri, R., Castradori, D., and Di Stefano, E., 1998. The Gelasian Stage (Upper Pliocene): A new unit of the global standard chronostratigraphic scale: Episodes, 21, pp. 82-87.

Salvador, A., 2006a. The Tertiary and the Quaternary are here to stay: AAPG Bulletin, 90, pp. 21-30.

Salvador, A., 2006b. A stable Cenozoic geologic time scale is indispensable: Episodes, 29, pp. 43-45.

Sigman, D.M., Jaccard, S.L., and Haug, G.H., 2004. Polar ocean stratification in a cold climate: Nature, 428, pp. 59-63.

Suc, J.-P., Bertini, A., Leroy, S.A.G., and Suballyova, D., 1997. Towards the lowering of the Pliocene/Pleistocene boundary to the Gauss-Matuyama reversal: Quaternary International, 40, pp. 37-42.

Sun, Y.B., Clemens, S.C., An, Z.H., and Yu, Z.W., 2006. Astronomical timescale and palaeoclimatic implication of stacked 3.6-Myr monsoon records from the Chinese Loess Plateau: Quaternary Science Reviews, 25 , pp. $33-48$.

St. John, K.E.K., 2004. Evidence that's an ocean apart: co-varying records of ice-rafted debris flux and Plio-Pleistocene bipolar ice sheet disintegration: The Sedimentary Record, 2, pp. 4-8.

Vaccari, E., 2006. The "classification" of mountains in eighteenth century Italy and the lithostratigraphic theory of Giovanni Arduino (1714-1795): Geological Society of America Special Paper, 411, pp. 157-177.

Versteegh, G.J.M., 1997. The onset of major Northern Hemisphere glaciations and their impact on dinoflagellate cysts and acritarchs from the Singa section, Calabria (southern Italy) and DSDP Holes 607/607A (North Atlantic): Marine Micropaleontology, 30, pp. 319-343.

Walsh, S.L., 2006. Hierarchical subdivision of the Cenozoic Era: A venerable solution, and a critique of current proposals: Earth-Science Reviews, 78, pp. 207-237.

Walsh, S.L., in press. The Neogene: origin, adoption, evolution, and controversy: Earth-Science Reviews.

Willis, K.J., Kleczkowski, A., and Crowhurst, S.J., 1999. 124,000-year periodicity in terrestrial vegetation change during the late Pliocene epoch Nature, 397, pp. 685-688.

\begin{abstract}
Martin J. Head is Professor and Chair-Elect of the Department of Earth Sciences at Brock University. He was previously at the University of Cambridge, and before that spent 14 years at the University of Toronto where he maintains a cross-appointment. He is a member of the ICS Subcommission on Quaternary Stratigraphy, and of its Working Group on the Lower-Middle Pleistocene Boundary. He is also a member of the INQUA Stratigraphy \& Chronology Commission. His interests include Cenozoic stratigraphy and marine palynology. Martin holds a PhD from the University of Aberdeen.
\end{abstract}

Philip Gibbard is Professor of Quaternary Palaeoenvironments at the University of Cambridge, United Kingdom, and chair of the International Commission on Stratigraphy's Subcommission on Quaternary Stratigraphy. He is also a member, and was formerly Secretary, of the Stratigraphy and Geochronology Commission of INQUA, the INQUA Subcommission of European Quaternary Stratigraphy and the Geological Society of London's Stratigraphy Commission. His research is focused on terrestrial and shallow marine sedimentation, stratigraphy and environmental evolution throughout Europe, but he has also worked in the Arctic, North America and South-East Asia.

\section{In Memorium Amos Salvador 1923-2007}

Amos Salvador was Professor Emeritus in the Department of Geological Sciences at The University of Texas at Austin. He was well known for his contributions to stratigraphic classification, research on the Gulf of Mexico and writings on the future of

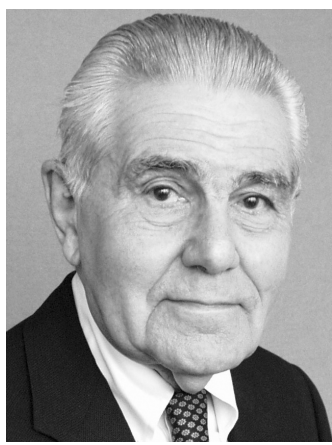
energy resources. As Chair of the International Commission on Stratigraphy's Subcommission on Stratigraphic Classification, he was the Editor of the second edition of the International Stratigraphic Guide (1994) and co-editor of an abridged version. Through these publications Salvador contributed to international agreement on principles of stratigraphic classification, making possible greater communication, coordination and understanding of some of geology's fundamental systems of classification. Previously, he worked for the Mene Grande Oil Company, a Venezuelan subsidiary of Gulf Oil, where he was advised by Hollis Hedberg, who later taught at Princeton University. Salvador was awarded a Ph.D., which he completed in 1950, at Stanford University. From 1950 to 1955, he was employed by Gulf Oil as a regional and surface geologist covering North Africa, Europe and South America. He left Gulf Oil in 1955 to join an affiliate of Esso (now ExxonMobil) in Venezuela and then until 1980 for several Esso affiliates. He retired as chief geologist of the Exxon Company, U.S.A. in 1980 to take up a position in the Department of Geological Sciences in The University of Texas at Austin, where he was first the Alexander Deussen Professor of Energy Resources and, after 1990, the Morgan J. Davis Professor of Petroleum Geology. The Department of Geological Sciences recognised Salvador's dedicated teaching by awarding him the Houston Oil \& Minerals Corporation Faculty Excellence Award in 1988.

In recent years, Salvador made it a mission to protest against efforts by the International Commission on Stratigraphy to eliminate the Tertiary and Quaternary periods from official classifications of the geological time scale. Although the Tertiary and Quaternary are widely accepted and used as periods within the Cenozoic Era, both terms were omitted from the Geologic Time Scale published in 2004. Salvador contended this was folly and that 'the Tertiary and the Quaternary are here to stay', as long as geologists continue to use the terms.

He died, aged 84, on 2nd December 2007 of complications from pneumonia and a malignant brain tumour. He is survived by his wife Lynn, and his children Phillip, Michael and Rosario.

This volume of papers is dedicated to his memory. We are indebted to Mark Cloos (Department of Geological Sciences, The University of Texas at Austin) for allowing us to reproduce excerpts from his obituary of Amos Salvador.

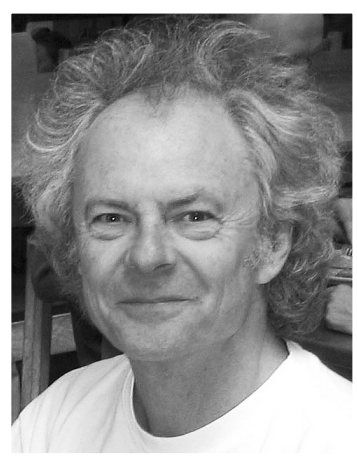

Philip Gibbard \& Martin J. Head 